\title{
URGENSI KETENTUAN ZONASI PASAR TRADISIONAL DENGAN PASAR MODERN PADA PERATURAN DAERAH KOTA SURABAYA NOMOR 1 TAHUN 2010 DALAM ASPEK HUKUM PERSAINGAN USAHA
}

Oleh

\author{
Oemar Moechtar*
}

\begin{abstract}
Abstrak
Salah satu bidang usaha yang paling banyak diminati pelaku usaha saat ini adalah bidang ritel, kenyataan tersebut ditandai dengan bermunculannya toko-toko modern seperti minimarket, supermarket, department store dan hypermarket. Penetrasi pasar modern di kota Surabaya membawa dampak buruk bagi pelaku usaha di pasar tradisional dan pedagang-pedagang menengah ke bawah yang mayoritas bermodal kecil. Semakin tinggi jumlah pasar modern di Surabaya akan menyebabkan semakin termarginalkannya pasar tradisional di Surabaya. Diperlukan suatu aturan khusus mengenai zonasi antara pasar modern dan pasar tradisional, agar tercipta suatu persaingan usaha yang sehat, serta untuk mewujudkan sinergi yang saling memerlukan dan memperkuat antara pasar tradisional dengan pasar modern agar dapat tumbuh berkembang lebih cepat sebagai upaya terwujudnya tata niaga dan pola distribusi yang mantap, lancar, efisien dan berkelanjutan. Pemerintah kota Surabaya telah mengatur mengenai masalah antara pasar modern dengan pasar tradisional dalam Peraturan Daerah kota Surabaya Nomor 1 Tahun 2010, namun materi muatan dalam Peraturan Daerah kota Surabaya Nomor 1 Tahun 2010 tersebut dinilai berpihak kepada peritel besar (pasar modern) dibandingkan dengan pelaku usaha pasar tradisional.
\end{abstract}

Keywords: Zonasi, Pasar Tradisional - Pasar Modern, Peraturan Daerah Kota Surabaya Nomor 1 Tahun 2010 .

\section{Pendahuluan}

Perkembangan suatu kota sangat erat kaitannya dengan perubahan pola pemanfaatan lahan. Meningkatnya pertumbuhan penduduk mengakibatkan meningkatnya permintaan lahan untuk melakukan berbagai kegiatan, dimana pengguna lahan akan berusaha memaksimalkan pemanfaatan lahan yang tercermin dari semakin meningkatnya usaha-usaha pemanfaatan lahan. Salah satu kegiatan yang produktif adalah kegiatan perdagangan. Meningkatnya kebutuhan masyarakat dewasa ini merupakan alasan utama bagi pelaku usaha ${ }^{1}$ untuk tetap bertahan dalam dunia bisnis. Pelaku usaha selalu mencari cara untuk dapat memiliki

\footnotetext{
Kantor Notaris Tandyo Hasan, oemar.office@ yahoo.com

${ }^{1}$ Pelaku usaha adalah setiap orang perorangan atau badan usaha, baik yang berbentuk badan hukum atau badan hukum yang didirikan dan berkedudukan atau melakukan kegiatan di wilayah hukum negara Republik Indonesia, baik sendiri maupun bersama-sama melalui perjanjian, menyelenggarakan berbagai kegiatan usaha dalam bidang ekonomi. (Undang-Undang No. 5 tahun 1999 tentang Larangan Praktek Monopoli dan Persaingan Usaha Tidak Sehat, LN tahun 1999 No. 33, TLN No. 3817, ps. 1 ayat 5)
} 
posisi yang menguntungkan bagi usahanya. Pelaku usaha harus dapat bersaing secara sehat dengan pelaku usaha yang lain agar dapat bertahan dalam pasar yang bersangkutan.

Tempat untuk memenuhi kebutuhan masyarakat kebutuhan sehari-hari tersebut umumnya adalah di pasar tradisional. Pasar tradisional dengan ciri khasnya yaitu terdapat proses tawar-menawar antara penjual dengan calon pembeli walaupun terkadang banyak ditemukan di beberapa wilayah di Indonesia bahwa fasilitas di pasar tradisional cenderung kumuh, gerah dan tidak memberikan suasana yang nyaman bagi konsumen yang berbelanja di pasar tradisional. Pesatnya proses modernisasi, industrialisasi, komersialisasi dan edukasi yang terpusat dikota-kotabesar telah menjadi faktor penggerak perubahan dan penarik arus urbanisasi dan migrasi penduduk di daerah Indonesia. Kota menjanjikan bagi penduduk yang tinggal di daerah pedesaan atau di daerah lain di Indonesia ${ }^{2}$.

Perkembangan Surabaya menjadi kota metropolis telah menarik para pelaku usaha untuk mengoperasikan pusat perbelanjaan dan pasar modern seperti supermarket maupun hypermarket. Kenyataan itu ditandai dengan bermunculannya toko-toko modern seperti minimarket ${ }^{3}$, supermarket ${ }^{4}$

\footnotetext{
2 Jurusan Sejarah Universitas Airlangga, Kota Lama, Kota Baru: Sejarah kota-kota di Indonesia Sebelum dan Setelah Kemerdekaan, Ombak, Yogyakarta, 2005. h.31

3 Minimarket adalah sarana atau tempat usaha untuk melakukan penjualan barang-barang kebutuhan seharihari secara eceran langsung kepada konsumen dengan cara pelayanan mandiri (swalayan);

4 Supermarket adalah sarana atau tempat usaha untuk melakukan penjualan barang-barang kebutuhan rumah tangga termasuk kebutuhan sembilan bahan pokok secara eceran dan langsung kepada konsumen dengan cara
}

,department store $^{5}$, hypermarket ${ }^{6}$ ataupun grosir yang berbentuk perkulakan yang memiliki jaringan global yang berdiri diberbagai wilayah kota Surabaya sejak beberapa tahun terakhir. Pada tahun 2009, tercatat lebih dari 210 minimarket tersebar di 31 kecamatan di Surabaya. Artinya ratarata di setiap kecamatan terdapat tujuh minimarket.Jumlah tersebutbelum termasuk supermarket maupun hypermarket yang mecapai 10 gerai. Pada tahun 2010, jumlah tersebut terus bertambah seiring semakin gencarnya pembangunan mall-mall baru di kota Surabaya ${ }^{7}$.

Perlu juga dicermati pola sebaran minimarket dan supermarket tersebut sangat tampak tidak terkendali. Di kawasan Surabaya Selatan, misalnya, berdiri 48 persen di antara keseluruhan pasar modern di Surabaya. Hal itu mengindikasikan bahwa tidak ada regulasi yang mengatur sebaran pasar modern agar terdistribusi secara seimbang. Dengan kata lain, pertumbuhan pasar modern di Surabaya bergerak begitu tidak terkendali ${ }^{8}$.

Tersebarnya toko-toko modern yang tidak teratur ini, dapat menyebabkan

pelayanan mandiri;

${ }^{5}$ Department Store adalah sarana atau tempat usaha untuk menjual secara eceran barang konsumsi utamanya produk sandang dan perlengkapannya dengan penataan barang berdasarkan jenis kelamin dan/tingkat usia konsumen;

${ }^{6}$ Hypermarket adalah sarana atau tempat usaha untuk melakukan penjualan barang-barang kebutuhan rumah tangga termasuk kebutuhan sembilan bahan pokok secara eceran dan langsung kepada konsumen, yang didalamnya terdiri atas pasar swalayan, toko modern dan toko serba ada yang menyatu dalam satu bangunan yang pengelolaannya dilakukan secara tunggal;

7 Saiful Arif, "Nasib Pasar Tradisional di Indonesia", http://gagasanhukum.wordpress. com/2009/12/, 2009, diakses pada tanggal 22 Juli 2010.

${ }^{8}$ Ibid. 
persaingan yang tidak seimbang antara pasar tradisional dengan pasar modern yang ternyata pasar modern menjual produk yang hampir sama dengan produk dalam pasar tradisional dan bahkan harga produk yang dijual di pasar tradisional relatif lebih murah dibawah harga pasaran. Jumlah pasar tradisional di Surabaya saat ini tercatat 81 unit pasar, namun semakin hari jumlah pedagang dan pembeli dalam pasar tradisional relatif terus menurun.

Pasar tradisional jika dikaji secara jernih, memang memiliki beberapa fungsi penting yang tidak dapat digantikan begitu saja oleh pasar modern. Setidaknya ada empat fungsi ekonomi yang sejauh ini dapat diperankan oleh pasar tradisional yaitu pertama pasar tradisional merupakan tempat dimana masyarakat berbagai lapisan memperoleh barang-barang kebutuhan harian dengan harga yang relatif terjangkau, karena memang sering kali relatif lebih murah dibandingkan harga yang ditawarkan pasar modern. Dengan kata lain pasar tradisional merupakan pilar penyangga perekonomian masyarakat kecil. Kedua, pasar tradisional merupakan tempat yang relatif lebih bisa dimasuki oleh pelaku ekonomi lemah yang menempati posisi mayoritas dari sisi jumlah. Pasar tradisional jelas jauh lebih bisa diakses oleh sebagian besar pedagang terutama yang bermodal kecil dari pada pasar modern. Ketiga, pasar tradisional merupakan salah satu sumber Pendapatan Asli Daerah lewat retribusi yang ditarik dari para pedagang tradisional. Keempat, akumulasi aktivitas jual beli di pasar tradisional merupakan faktor penting dalam penghitungan tingkat pertumbuhan ekonomi baik pada skala lokal, regional maupun nasional.

Disamping fungsi ekonomi diatas, pasar tradisional juga memiliki beberapa fungsi sosial antara lain: pertama, pasar tradisional merupakan ruang penampakan wajah asli masyarakat yang saling tergantung karena saling membutuhkan. Kedua, pasar tradisional adalah tempat bagi masyarakat terutama dari kalangan bawah untuk melakukan interaksi sosial dan melakukan diskusi informal atas segenap permasalahan yang sedang mereka hadapi.

Kehadiran pasar modern di wilayah perkotaan di Indonesia memberikan implikasi negatif dari aspek fisik, lingkungan, transportasi, sosial dan ekonomi ${ }^{9}$ . Keberadaan pasar modern ternyata mampu munyulut gejolak sosial dari pedaganng pasar tradisional akibat menurunnya minat masyarakat untuk berbelanja di pasar tradisional. Keberadaan pasar tradisional di perkotaan dari waktu ke waktu semakin terancam dengan semakin maraknya pembangunan pasar modern. Pangsa pasar dan kinerja usaha pasar tradisional menurun, sementara pada saat yang sama pasar modern mengalami peningkatan.

Melihat kenyataan tersebut, pasar tradisional dengan pasar modern tidak layak disebut sebagai sebuah persaingan, tapi lebih pada praktek dominasi pasar modern terhadap pasar tradisional, meskipun kedua jenis pasar tersebut tetap diangggap sebagai persaingan, persaingan tersebut harus

${ }^{9}$ Direktur Jenderal Cipta Karya, Departemen Pekerjaan Umum. 2006. 
disebut sebagai persaingan yang sama sekali tidak sehat (persaingan usaha tidak sehat). Indikator dikatakan bahwa persaingan usaha itu tidak sehat yaitu, kembali kepada definisi persaingan usaha tidak sehat yang diberikan oleh Undang-Undang Nomor 5 Tahun 1999 khususnya Pasal 1 angka 6:

"Persaingan usaha tidak sehat adalah persaingan antar pelaku usaha dalam menjalankan kegiatan produksi dan atau pemasaran barang dan atau jasa yang dilakukan dengan cara tidak jujur atau melawan hukum atau menghambat persaingan usaha"

Dengan demikian persaingan usaha tidak sehat itu adalah setiap kegiatan usaha yang mengandung unsur-unsur 10 :

1. Ada cara yang tidak jujur dalam kegiatan usaha, baik di bidang produksi maupun pemasaran;

2. Cara yang dilakukan itu merupakan perbuatan melawan hukum;

3. Perbuatan melawan hukum itu bertujuan untuk meniadakan persaingan;

4. Ada unsur perbuatan restrictive trade practice atau barrier to entry;

5. Perbuatan itu dilakukan antar sesama pelaku usaha;

Pemerintah harus segera melakukan langkah-langkah strategis untuk melindungi

${ }^{10}$ Elyta Ras Ginting, Hukum Anti Monopoli Indonesia(Analisis dan Perbandingan Undang-Undang Nomor 5 Tahun 1999), Citra Aditya Bakti, Bandung, 2001. pasar tradisional dari serangan pasar modern yang membabi buta sekarang ini. Diantaranya, pertama, menciptakanregulasi untuk mengendalikan keseimbangan pasar tradisional dengan pasar modern, perizinan merupakan poin penting dalam hal berdirinya suatu pasar. Regulasi perizinan berkaitan dengan pemenuhan dokumen-dokumen administrasi yang meliputi Surat Izin Usaha Perdagangan (SIUP), Izin Mendirikan Bangunan (IMB), Izin Gangguan (Hinder Ordonantie) serta perizinan khusun lain.

Kedua, regulasi penataan. Regulasi ini harus diterapkan bersamaan dengan dokumen-dokumen perizinan. Termasuk dalam penataan ini adalah regulasi zonasi pasar modern dengan pasar tradisional.

Kebijakan zonasi kawasan saat ini banyak diterapkan di negara-negara Eropa sepertiFinlandia, Swiss, Swediadan Bulgaria yang efektif untuk mereduksi gesekan antara pasar tradisional dan pasar modern ${ }^{11}$ - Terdapat kawasan-kawasan tertentu yang memang diperuntukkan bagi pasar modern dan pasar tradisional. Namun di Surabaya, zonasi kawasan itu tidak diterapkan secara baik. Karena itu tidak heran, banyak minimarket di tengah-tengah perkampungan, bahkan langsung berhadap-hadapan dengan pasar tradisional.

Zonasi rasio penduduk perlu juga dipertimbangkan dalam pemberian izin pasar modern. Tidak adanya zonasi ini mengakibatkan banyak pasar modern yang menumpuk di wilayah tertentu, sehingga tidak sebanding dengan pangsa pasar yang

\footnotetext{
${ }^{11}$ Saiful Arif, op.cit.
} 
otomatis mematikan pangsa pasar tradisional yang lebih dahulu ada. Proporsi rasio yang dapat dilakukan misalnya: dalam setiap 500 ribu penduduk, hanya dapat dibangun satu supermarket atau hypermarket dan dua ritel minimarket. Tidak seperti yang terjadi saat ini, dalam satu kecamatan bisa berdiri empat supermarket atau hypermarket dan 10 hingga 15 minimarket, padahal penduduknya tidak lebih dari 350 ribu jiwa ${ }^{12}$.

Ketiga, regulasi pengawasan dan penegakkan hukum. Ketentuan perizinan dan penataan tersebut merupakan konsep normatif yang harus direalisakan di lapangan secara konsisten dan berwibawa. Pemerintah kota harus memiliki instrument pengawasan dan penegakan hukum sematamata untuk menciptakan persaingan usaha yang sehat, adil dan manusiawi.

Keempat, regulasi pembinaan pasarpasar tradisional, dimana pasar tradisional harus diberi treatment khusus agar mampu berkembang dan bersaing dengan pasar modern. Pemerintah harus mempunyai program-program pembinaan, misalnya mengupayakan sumber-sumber alternatif pendanaan untuk pemberdayaan pasar tradisional sesuai peraturan perundangundangan yang berlaku, meningkatkan kompetensi pedagang dan pengelola pasar tradisional, memprioritaskan memperoleh tempat usaha bagi pedagang pasar tradisional yang telah ada sebelum dilakukan renovasi atau relokasi pasar tradisioanl, serta mengevaluasi pengelolaan

\footnotetext{
${ }^{12}$ Apriana Anna, "Pasar Tradisional vs Pasar Modern”, http://apriana-anna.blogspot.com/2010/05/ pasar-tradisional-vs-hypermart.html, diakses pada tanggal 24 Juni 2010
}

pasar tradisional.

Pemerintah dalam hal ini Presiden Republik Indonesia telah memberikan solusi untuk mengatasi masalah ini, yaitu dengan mengeluarkan regulasi pada tanggal 27 Desember 2007 berupa Peraturan Presiden Nomor 112 Tahun 2007 Tentang Penataan dan Pembinaan Pasar Tradisional, Pusat Perbelanjaan, dan Toko Modern. Serta Petunjuk Pelaksanaan Peraturan Presiden tersebut adalah Peraturan Menteri Perdagangan Republik Indonesia Nomor: 53/M-DAG/PER/12/2007 Tentang Pedoman Penataan dan Pembinaan Pasar Tradisional, Pusat Perbelanjaan dan Toko Modern.

Namun, keberadaan Peraturan Presiden Nomor 112 Tahun 2007 serta Peraturan Menteri Perdagangan Republik Indonesia Nomor: 53/M-DAG/PER/12/2007 yang diharapkan dapat memberikan "angin segar" bagi para pelaku ritel tradisional ternyata tidak sesegar yang didengungkan, Pasalnya isi dari Peraturan Presiden dan Peraturan Menteri Perdagangan tersebut masih abuabu, kedua regulasi tersebut tidak mengatur tentang jarak antara toko modern dengan pasar tradisional secara spesifik.

Keberadaan Peraturan Presiden Nomor 112 Tahun 2007 serta Peraturan Menteri Perdagangan Republik Indonesia Nomor: 53/M-DAG/PER/12/2007 juga belum mampu memberikan iklim usaha yang kondusif bagi keberlangsungan pasar tradisional, sehingga banyak ditemukan bangunan-bangunan toko modern yang tidak teratur dan menyebar di berbagai wilayah tanpa memperhatikan Rencana 
Tata Ruang Wilayah Kota Surabaya yang berlaku selama ini.

Sebagai tindak lanjut dari terbitnya Peraturan Presiden Nomor 112 Tahun 2007 serta Peraturan Menteri Perdagangan Republik Indonesia Nomor: 53/MDAG/PER/12/2007, Pemerintah Kota Surabaya menerbitkan Peraturan Daerah Kota Surabaya Nomor 1 Tahun 2010 tentang Penyelenggaran Usaha di Bidang Perdagangan dan Perindustrian, sebagai regulasi untuk mengatasi masalah antara pasar tradisional dengan pasar modern. Peraturan Daerah Kota Surabaya Nomor 1 Tahun 2010 tetap tidak dapat mengakomodir kepentingan pelaku usaha khususnya pelaku usaha dalam pasar tradisional. Peraturan Daerah Kota Surabaya Nomor 1 Tahun 2010 dirasa masih belum memihak kepada rakyat, sama halnya dengan Peraturan Presiden Nomor 112 Tahun 2007 serta Peraturan Menteri Perdagangan Republik Indonesia Nomor: 53/M-DAG/PER/12/2007.

Bertolak dari keberadaan Peraturan Daerah Kota Surabaya Nomor 1 Tahun 2010, kabupaten bantul juga memiliki peraturan daerah serupa atas tindak lanjut dari diterbitkannya Peraturan Presiden Nomor 112 Tahun 2007, yaitu Peraturan Bupati Bantul Nomor 12 Tahun 2010 juncto Peraturan Bupati Bantul Nomor 34 Tahun 2010, dimana materi yang terkandung di dalam Peraturan Bupati Bantul tersebut lebih spesifik dan lebih terperinci dibandingkan dengan Daerah Kota Surabaya Nomor 1 Tahun 2010. Penulis dalam hal ini memilih untuk meneliti Peraturan Bupati Bantul Nomor 12 Tahun 2010 juncto Peraturan
Bupati Bantul Nomor 34 Tahun 2010, karena materi muatan dalam Peraturan Bupati Bantul Nomor 12 Tahun 2010 juncto Peraturan Bupati Bantul Nomor 34 Tahun 2010 tersebut dapat dinilai lebih pro kepada pasar tradisional dibandingkan dengan pasar modern yang ada di kabupaten bantul dan pengaturan mengenai zonasi pasar lebih terperinci dibadingkan peraturan daerah kota lain yang mengatur hal serupa.

\section{Arti Penting Zonasi Bagi Persaingan Usaha}

Bila kita membicarakan zonasi, pasti yang terlintas dalam pikiran kita adalah jarak. Zonasi berasal dari kata zona, zona adalah kawasan atau area yang memiliki fungsi dan karakteristik lingkungan yang spesifik ${ }^{13}$ .Zonasi dalam bahasa Inggris adalah zoning. Zoning merupakan pembagian kawasan ke dalam beberapa zona sesuai dengan fungsi dan karakteristik semula atau diarahkan bagi pengembangan fungsi-fungsi lain ${ }^{14}$.

Peraturan Zonasi (Zoning Regulation) dapat didefinisikan sebagai ketentuan yang mengatur tentang klasifikasi, notasi dan kodifikasi zona-zona dasar, peraturan penggunaan, peraturan pembangunan dan berbagai prosedur pelaksanaan pembangunan ${ }^{15}$. Peraturanzonasimerupakan ketentuan yang mengatur pemanfaatan ruang dan unsur-unsur pengendalian yang disusun untuk setiap zona peruntukan sesuai dengan rencana rinci tata ruang.

Berdasarkan penjelasan Pasal 36 ayat

${ }^{13}$ Ismail Marzuki, “Zoning”, http://imazu.wordpress. com/zoning/, diakses pada tanggal 10 Oktober 2010.

${ }^{14}$ Ibid

${ }^{15}$ Ibid 
1, Undang Undang Nomor 26 Tahun 2007 tentang Penataan Ruang (Lembaran Negara Republik Indonesia Tahun 2007 Nomor 68, Tambahan Lembaran Negara Republik Indonesia Nomor 4725), menyebutkan bahwa:

Peraturan zonasi berisi ketentuan yang harus, boleh dan tidak boleh dilaksanakan pada zona pemanfaatan ruang yang dapat terdiri atas ketentuan tentang amplop ruang (koefisien dasar ruang hijau, koefisien dasar bangunan, koefisien lantai bangunan, dan garis sempadan bangunan), penyediaan sarana dan prasarana, serta ketentuan lainyangdibutuhkanuntukmewujudkan ruang yang aman, nyaman, produktif, dan berkelanjutan.

Peraturan zonasi mengenai pasar dalam hukum positif di Indonesia antara lain diatur dalam Peraturan Presiden Nomor 112 Tahun 2007 tentang Penataan dan Pembinaan Pasar Tradisional, Pusat Perbelanjaan dan Toko Modern dan Peraturan Menteri Perdagangan Nomor 53/M-DAG/PER/12/2008 tentang Pedoman Penataan dan Pembinaan Pasar Tradisional, Pusat Perbelanjaan dan Toko Modern sebagai juklak (Petunjuk Pelaksanaan) dari Peraturan Presiden Nomor 112 Tahun 2007.

Persaingan adalah usaha memperlihatkan keunggulan masing-masing yang dilakukan oleh perseorangan (perusahaan, negara) pada bidang perdagangan, produksi dan persenjataan dan sebagainya ${ }^{16}$

${ }_{16}$ Departemen Pendidikan dan Kebudayaan, Kamus Besar Bahasa Indonesia, Balai Pustaka, 1989, h.767.
- Sedangkan yang dimaksud dengan persaingansehatmerupakansuatuperjuangan yang dilakukan oleh seseorang atau kelompok tertentu (kelompok sosial), agar memperoleh kemenangan atau hasil secara kompetitif, tanpa menimbulkan ancaman atau benturan fisik di pihak lawannya. Porter menjelaskan cakupan persaingan yang dapat menjadi landasan fundamental bagi kinerja (performance) di atas rata-rata untuk jangka panjang dan dinamakannya keunggulan bersaing yang lestari (sustainable competitive advantage) dan dapat diperoleh melalui tiga srategi generik ${ }^{17}$

Adanya persaingan bagi Pakpahan akan menghindarkan terjadinya konsentrasi kekuatan pasar(market power) pada satu atau beberapa perusahaan. Ini berarti konsumen mempunyai banyak alternatif dalam memilih barang dan jasa yang dihasilkan produsen yang begitu banyak sehingga harga benarbenar ditentukan oleh pasar permintaan dan penawaran, bukan oleh hal-hal lain.

Pasar persaingan sempurna (perfect competition) adalah sebuah jenis pasar dengan jumlah penjual dan pembeli yang sangat banyak dan produk yang dijual bersifat homogen. Harga terbentuk melalui mekanisme pasar dan hasil interaksi antara penawaran dan permintaan sehingga penjual dan pembeli di pasar ini tidak dapat mempengaruhi harga dan hanya berperan

17 Johnny Ibrahim, Hukum Persaingan Usaha, Filosofi, Teori, dan Imlikasi Penerapannya di Indonesia, Bayumedia Publishing, Malang, 2006, h.103, dikutip dari Michael E. Porter, Competitive Advantage, Creating and Sustaining Superior Performance Edisi Indonesia: Keunggulan Bersaing Menciptakan dan Mempertahankan Kinerja Unggul, alih bahasa: Agus Dharma dkk., Erlangga, Jakarta, 1993, hlm. 10-11. 
sebagai penerima harga (price taker). Barang dan jasa yang dijual di pasar ini bersifat homogen dan tidak dapat dibedakan, semua produk terlihat identik. Pembeli tidak dapat membedakan apakah suatu barang berasal dari produsen $\mathrm{A}$, produsen $\mathrm{B}$ atau produsen $\mathrm{C}$, oleh karena itu, promosi dengan iklan tidak akan memberikan pengaruh terhadap penjualan produk.

Dengan adanya zonasi ini bagi persaingan usaha adalah seolah-olah tiap pelaku usaha memiliki "wilayah pasar"nya sendiri, agar pelaku usaha dalam menjalankan usahanya dapat menjadi mitra usaha yang baik dan antar pelaku usaha dapat menjalankan usahanya dengan persaingan yang sehat (fair trade) tanpa adanya unsur saling mematikan antar pelaku usaha. Dari adanya persaingan sehat ini diharapkan akan terciptanya pasar persaingan sempurna (perfect competition) yang jauh dari usaha pelaku usaha menguasai pasar yang bersangkutan dengan cara yang nonfair. Mengenai pentingnya zonasi dalam suatu persaingan usaha dapat diilustrasikan dengan bagan di bawah ini:

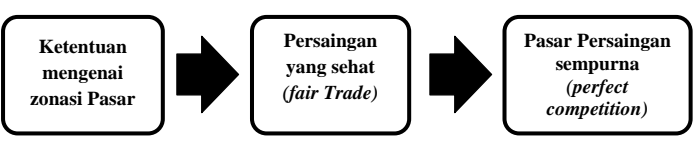

Bagan I: Ilustrasi Pentingnya Zonasi bagi Persaingan Usaha

\section{Penerapan Peraturan Zonasi dalam Peraturan Daerah}

Keberadaan kegiatan perdagangan skala besar seperti pasar modern sudah menjadi bagian yang tidak terpisahkan dalam kehidupan masyarakat perkotaan.
Hal inilah yang menjadi pertimbangan investor asing untuk masuk kedalam jalur perdagangan di Indonesia, sehingga banyak bermunculan toko modern berupa minimarket, supermarket, department store danhypermarket. Tokomoderninijumlahnya semakin tahun semakin bertambah dan tersebar hampir diluruh pelosok daerah.

Untuk mengatasi masalah ini, pada akhir tahun 2007 pemerintah melakukan intervensi kebijakan melalui Peraturan Presiden Nomor 112 Tahun 2007 tentang Penataan dan Pembinaan pasar tradisional, pusat perbelanjaan dan toko modern. Pasal 3 ayat (1)Peraturan Presiden Nomor 112 Tahun 2007 menyebutkan bahwa lokasi pendirian toko modern wajib mengacu pada Rencana Tata Ruang Wilayah Kabupaten/Kota, dan Rencana Detail Tata Ruang Kabupaten/Kota, termasuk peraturan zonasinya. Dalam hal ini Pemerintah Pusat menyerahkan kewenangan mengenai kewilayahan kepada Pemerintah Daerah. Propinsi Jawa Timur menerbitkan Peraturan Daerah Nomor 30 Tahun 2008 tentang Perlindungan, Pemberdayaan Pasar Tradisional dan Penataan Pasar Modern di Jawa Timur. Isinya antara lain mengatur tentang lokasi pendirian pasar modern yang wajib mengacu pada Rencana Tata Ruang Wilayah Kabupaten/Kota dan Rencana Detail Tata Ruang Kabupaten/Kota, termasuk peraturan zonasinya. Dalam hal ini pemerintah Propinsi Jawa Timur member kewenangan kepada pemerintah kabupaten/ kota.

Pesatnya perkembangan toko modern tampaknya tidak diimbangi dengan upaya menanggulangi dampak yang ditimbulkan 
baik dari aspek fisik maupun aspek nonfisik. Apabila melihat dalam ketentuan Peraturan Daerah kota Surabaya Nomor 3 Tahun 2007 tentang Rencana Tata Ruang Wilayah kota Surabaya (Lembaran Daerah Kota Surabaya Tahun 2007 Nomor 3, Tambahan Lembaran Daerah Kota Surabaya Nomor 3, selanjutnya disebut RT/RW Surabaya), toko modern boleh berdiri dimana saja asalkan lokasinya di kawasan perdagangan dan jasa. Namun dalam praktek sekarang banyak toko modern yang melanggar ketentuan ini, masih ada toko modern yang berdiri di luar kawasan perdagangan dan jasa. Pola perkembangan toko modern sudah semakin berkembang, toko modern tersebut distribusinya tidak merata dan dibangun di kawasan-kawasan strategis. Toko modern memperoleh kemudahan memperoleh ijin lokasi akibat belum tepatnya sebuah pengaturan perijinan lokasi dan aturan zonasi yang mengatur secara lebih spesifik kebutuhan lokasi toko modern dalam RT/RW. Jika tidak segera diatur melalui penataan zonasi toko modern di Surabaya, jelas dapat menjadi dampak baik dari segi fisik, lingkungan, tata ruang maupun transportasi.

Pada tahun 2010, tepatnya pada tanggal 22 Maret 2010 Pemerintah Kota Surabaya menerbitkan Peraturan Daerah Kota Surabaya Nomor 1 Tahun 2010 tentang Penyelenggaran Usaha di Bidang Perdagangan dan Perindustrian (Lembaran Daerah Kota Surabaya Tahun 2010 Nomor 1, Tambahan Lembaran Daerah Kota Surabaya Nomor 1) untuk mengatasi masalah toko modern yang semakin marak perkembangannya di
Surabaya. Peraturan Daerah Kota Surabaya Nomor 1 Tahun 2010 ini pada intinya diterbitkan untuk memperketat Surat Izin Usaha Perdagangan (SIUP) yang selama ini dimiliki oleh toko modern dengan ketentuan baru harus memiliki Izin Usaha Toko Modern (IUTM) sebagai pengganti SIUP. Apabila masa berlaku SIUP berakhir, pemilik SIUP harus segera menggantinya dengan IUTM. Kepala Dinas Perindustrian dan Perdagangan kota Surabaya, Endang Tjatur Rahmawati menjelaskan bahwa untuk mendapatkan IUTM, tidak gampang, pengusaha harus melengkapi syarat-syarat antara lain izin peruntukan, Izin Mendirikan Bangunan (IMB) dan izin gangguan (Hinder Ordonantie). Penerbitan surat-surat izin ini juga tidak mudah, harus sesuai peruntukan lahan dan lokasi ${ }^{18}$.

Namun sangat disayangkan, Peraturan Daerah Kota Surabaya Nomor 1 Tahun 2010 ini belum memberikan keterangan yang spesifik mengenai berapa jarak minimal pendirian sebuah toko modern dengan toko modern lain maupun jarak antara toko modern dengan pasar serta ritel tradisional. Dalam Pasal 37 Peraturan Daerah Kota Surabaya Nomor 1 Tahun 2010 ini hanya menyebutkan:

Lokasi untuk pendirian Toko Modern wajib memperhatikan:

a. Rencana Tata Ruang Wilayah Kota;

b. Rencana Detail Tata Ruang Wilayah Kota, termasuk peraturan zonasinya;

${ }^{18}$ Endang Tjatur Rahwati, "Minimarket Terancam Tutup, Tanpa Izin Usaha Toko Modern", Surya, 7 Mei, 2010, h. 3-4. 
c. Kondisi sosial ekonomi masyarakat dan keberadan Pasar Tradisional, Usaha Mikro, Kecil dan Menengah yang ada di wilayah yang bersangkutan; dan

d. Jarak antara Toko Modern yang akan didirikan dengan Pasar Tradisional yang telah ada sebelumnya;

Ketidakjelasan ketentuan Pasal 37 huruf d Peraturan Daerah Kota Surabaya Nomor 1 Tahun 2010 ini yang menyebabkan banyak toko modern dan Pemerintah Daerah kota Surabaya yang menerbitkan Izin Usaha Toko Modern mengalami pelanggaran, sehingga banyak ditemukan hampir di setiap sudut kota Surabaya toko modern yang pola penyebarannya tidak merata dan bahkan antara toko modern satu dengan toko modern lain saling berhadap-hadapan dan yang lebih parah lagi, toko modern tersebut berjarak sangat berdekatan dengan pasar tradisional serta ritel tradisional, yang berakibat melemahnya perekonomian para pedagang di pasar dan ritel tradisional.

Dalam bab ketentuan umum Undang Undang Nomor 26 Tahun 2007 (Lembaran Negara Republik Indonesia Tahun 2007 Nomor 68, Tambahan Lembaran Negara Republik Indonesia Nomor 4725), pengertian peraturan zonasi sama sekali tidak disebutkan. Namun dalam penjelasan umum angka 6 Undang Undang Nomor 26 Tahun 2007 , dijelaskan sebagai berikut:

Peraturan Zonasi merupakan ketentuan yang mengatur tentang persyaratan pemanfaatan ruang dan ketentuan pengendaliannya dan disusun untuk setiap blok/zona peruntukan yang penetapan zonanya dalam rencana rinci tata ruang.

Pada Penjelasan Pasal 36 Undang Undang Nomor 26 Tahun 2007, disebutkan:

Peraturan zonasi merupakan ketentuan yang mengatur pemanfaatan ruang dan unsur-unsur pengendalian yang disusun untuk setiap zona peruntukan sesuai dengan rencana rinci tata ruang.

Peraturan zonasi berisi ketentuan yang harus, boleh dan tidak boleh dilaksanakan pada zona pemanfaatan ruang yang dapat terdiri atas ketentuan tentang amplop ruang (koefisien dasar ruang hijau, koefisien dasar bangunan, koefisien lantai bangunan dan garis sempadan bangunan), penyediaan sarana dan prasarana, serta ketentuan lainyangdibutuhkanuntukmewujudkan ruang yang aman, nyaman, produktif dan berkelanjutan.

Peraturan zonasi merupakan suatu perangkat peraturan yang dipakai sebagai landasan dalam menyusun rencana tata ruang mulai dari jenjang rencana yang paling tinggi (rencana makro) sampai kepada rencana yang sifatnya operasional (rencana mikro) disamping juga akan berfungsi sebagai alat kendali dalam pelaksanaan pembangunan kota. Peraturan zonasi adalah buku manual bagi para planner dalam penyusunan rencana kota $^{19}$. Ketiadaan zoning dapat membuat rencana kota yang bersifat multi tafsir sehingga bisa dimanfaatkan untuk tujuan-tujuan yang menyimpang.

\footnotetext{
${ }^{19}$ Ismail Zubir, loc.cit.
} 
Tanpa adanya peraturan zonasi juga akan sangat sulit menyiapkan suatu rencana kota yang sifatnya operasional dan dapat dipertanggung jawabkan secara hukum. Rencana Umum Tata Ruang meskipun telah ditetapkan sebagai peraturan daerah, tetapi karena kandungan materinya masih sangat bersifat umum dan konsepsional, belum dapat dijadikan dasar dalam penerbitan berbagai macam perizinan yang menyangkut pembangunan kota.

Peraturan zonasi (zoning regulation) terdiri dari dua unsur yaitu ${ }^{20}$ :

1. Zoning Text/Zoning Statement

Zoning Text berisi aturan-aturan yang menjelaskan mengenai tata guna lahan dan kawasan, pemanfaatan yang diizinkan dan diizinkan dengan syarat, standar pengembangan, minimum lot requirement, dll.

2. Zoning Map

Zoning Map berisi pembagian blok peruntukan dengan ketentuan aturan untuk tiap blok peruntukan. Selain itu, zoning map menggambarkan mengenai tata guna lahan dan lokasi tiap fungsi lahan dan kawasan.

Dalam ketentuan Pasal 36 ayat (3) Undang Undang Nomor 26 Tahun 2007, disebutkan bahwa peraturan zonasi itu ditetapkan dengan:

a. Peraturan Pemerintah untuk arahan peraturan zonasi sistem nasional;

b. Peraturan Daerah provinsi untuk arahan peraturan zonasi sistem

${ }^{20}$ Gede Budi, loc.cit. provinsi; dan

c. Peraturan Daerah Kabupaten/Kota untuk peraturan zonasi

Karena wilayah yang dibahas dalam tulisan ini adalah wilayah kota Surabaya, maka peraturan zonasi yang dimaksud nantinya akan diterbitkan dalam Peraturan Daerah Kota Surabaya.

\section{Keterkaitan Zonasi dalam Undang- Undang Nomor 5 Tahun 1999}

Adanya Undang-Undang Nomor 5 Tahun 1999 tentang Larangan Praktek Monopoli dan Persaingan Usaha Tidak Sehat merupakan rambu-rambu dan batasan dalam mengakses "kue" pembangunan sehingga si besar tidak dengan seenaknya mengambil bagian si kecil. Batas-batas yang jelas merupakan pagar agar salah satu pihak melihat pihak lain bukan sebagai saingan melainkan sebagai mitra untuk bekerja sama $^{21}$.

Dalam Bab Ketentuan Umum Pasal 1 angka 6 Undang-Undang Nomor 5 Tahun 1999 disebutkan bahwa:

Persaingan usaha tidak sehat adalah persaingan antar pelaku usaha dalam menjalankan kegiatan produksi dan atau pemasaran barang dan atau jasa yang dilakukan dengan cara tidak jujur atau melawan hukum atau menghambat persaingan usaha.

Maksud dari kata melawan hukum (lebih tepatnya dikatakan melanggar hukum), jika dikaitkan dengan zonasi yaitu

${ }^{21}$ Gunawan Widjaja dan Ahmad Yani, Seri Hukum Bisnis: Anti Monopoli, Raja Grafindo Persada, Jakarta, 2000, h. 6. 
Izin Usaha Toko Modern (IUTM) yang telah diterbitkan oleh pejabat dalam hal ini walikota Surabaya tersebut sebenarnya telah melanggar ketentuan dari produk hukum diatasnya yaitu:

1. Undang Undang Dasar Negara Republik Indonesia Tahun 1945

2. Undang Undang Nomor 26 Tahun 2007 tentang Penataan Ruang

3. Peraturan Presiden Nomor 112 Tahun 2007 tentang Penataan dan Pembinaan Pasar Tradisional, Pusat Perbelanjaan dan Toko Modern

4. Peraturan Menteri Perdagangan Nomor 53/M-DAG/PER/12/2008 tentang Pedoman Penataan dan Pembinaan Pasar Tradisional, Pusat Perbelanjaan dan Toko Modern

5. Peraturan Daerah kota Surabaya Nomor 3 Tahun 2007 tentang Rencana Tata Ruang Wilayah kota Surabaya

Akibat dari adanya peraturan yang dilanggar ini, berdasarkan asas hukum Lex Superiori Derogat Legi Inferiori dimana peraturan hukum yang kedudukannya lebih tinggi dapat mengalahkan peraturan hukum yang lebih rendah. Izin yang diterbitkan oleh walikota ini jelas-jelas telah melanggar peraturan hukum diatasnya, sehingga dapat dibatalkan oleh pihak yang merasa dirugikan. Tanpa adanya gugatan pembatalan dari pihak yang berkepentingan, maka peraturan perundang-undangan tersebut dinyatakan masih tetap berlaku.

Pasar tradisional sebenarnya lebih menggambarkan denyut nadi perkonomian rakyat kebanyakan, yang merupakan cerminan dari ekonomi kerakyatan dan demokrasi kerakyatan sebagaimana diamanatkan dalam Pasal 34 Undang Undang Dasar Negara Republik Indonesia Tahun 1945. Di pasar tradisional, masih banyak orang yang menggantungkan hidupnya, dari mulai para pedagang kecil, kuli panggul, pedagang asongan, hingga tukang becak. Manfaat yang dihasilkan dari pembangunan pasar tradisional sangat besar kepada perekonomian daerah, baik melalui penyerapan tenaga kerja, stabilitas harga bahan pokok, pemberdayaan usaha mikro kecil dan menengah, maupun peningkatan kesejahteraan masyarakat. Sudah banyak kios di pasar tradisional yang harus tutup karena sulit bersaing dengan pasar modern. Data dari Asosiasi Pedagang Pasar Tradisional Seluruh Indonesia (APPSI) pada tahun 2005 seperti dikutip website Kementrian Koperasi dan Usaha Kecil Menengah menyebutkan, bahwa sekitar 400 toko di pasar tradisional harus tutup usaha setiap tahunnya. Jumlah ini kemungkinan akan terus bertambah seiring kehadiran pasar modern yang kian marak.

Dengan adanya pelanggaran pembangunan pasar modern ini menyebabkan tujuan dari Undang Undang Nomor 5 Tahun 1999 khususnya Pasal mengenai asas dan tujuan (Pasal 2 dan Pasal 3 Undang Undang Nomor 5 Tahun 1999) belum dapat tercapai. Salah satu tujuan yang belum tercapai adalah "meciptakan iklim usaha yang kondusif melalui pengaturan persaingan usaha yang sehat sehingga menjamin adanya kesempatan berusaha 
yang sama bagi pelaku usaha besar, pelaku usaha menengah dan pelaku usaha kecil".

Tidak adanya aturan yang jelas mengenai zonasi antara pasar tradisional dengan pasar modern dalam Peraturan Daerah Kota Surabaya Nomor 1 Tahun 2010, menyebabkan pelaku usaha khususnya pendiri toko modern dapat dengan sesuka hati memilih lokasi pendirian toko modernnya tanpa memperhatikan jika disekitar proyek tersebut telah terdapat pasar tradisional dan/ atau pasar modern. Kondisi inilah yang menyebabkan semakin terpuruknya pasar tradisional tidak hanya di kota Surabaya, namun juga pasar tradisional di seluruh kota di Indonesia.

Permasalah selanjutnya adalah pejabat selaku penerbit izin usaha bagi pelaku usaha yang hendak mendirikan toko modern, dalam hal ini adalah Walikota Surabaya. Walikota Surabaya sebelum menerbitkan izin usaha bagi toko modern, tidak memperhatikan kondisi di lapangan yang menjadi lokasi dalam permohonan penerbitan izin usaha toko modern (IUTM) apakah melanggar ketentuan dalam RT/RW, Peraturan Daerah Kota Surabaya Nomor 1 Tahun 2010, aspek sosial masyarakat di sekitar lokasi, aspek lingkungan dan aturan-aturan lain yang bersangkutan. Dalam prakteknya Walikota Surabaya hanya dapat menerbitkan izin usaha toko modern tersebut, tanpa melakukan survey terhadap lokasi yang dimohonkan, sehingga apabila toko modern tersebut telah selesai dibangun, maka akan menimbulkan masalah, "mengapa bisa ada toko modern di lokasi ini?".
Dikhawatirkan dengan selalu diterbitkannya Izin Usaha Toko Modern (IUTM) yang tiada hentinya ini di kota Surabaya, akan timbul persaingan usaha yang tidak sehat, karena pasar tradisional kalah jumlah dengan pasar modern, lambat laun pasar tradisional akan tersingkir dari permukaan dan terjadinya konsentrasi kekuatan pasar (market power) atau pemusatan kekuatan ekonomi ${ }^{22}$ pada satu atau beberapa perusahaan (toko modern). Jika terjadi konsentrasi kekuatan pasar, berarti konsumen tidak punya pilihan dalam memilih produk. Akibat dari adanya konsentrasi kekuatan pasar ini, pelaku usaha pada pasar modern dapat menentukan harga dengan sesuka hati karena harga benarbenar ditentukan oleh pasar permintaan dan penawaran, bukanoleh hal-hallain. Tidak ada pelaku usaha pesaing dalam relevan market yang bersangkutan, tidak ada persaingan maka akan terjadi pemusatan kekuatan pasar yang menyebabkan kesempatan berusaha menjadi semakin menyempit, dan dikhawatirkan dari adanya fenomena ini akan menimbulkan tindakan monopoli ${ }^{23}$ sebagaimana diatur dalam Undang Undang Nomor 5 Tahun 1999.

Dampak lain yang ditimbulkan dari pemusatan kekuatan ekonomi oleh pasar

${ }^{22}$ Pemusatan kekuatan ekonomi adalah penguasaan yang nyata atas suatu pasar bersangkutan oleh satu atau lebih pelaku usaha sehingga dapat menentukan harga barang dan atau jasa. (Undang-Undang No.5 Tahun 1999 tentang Larangan praktek monopoli dan persaingan usaha tidak sehat, LN Tahun 1999 No. 33, TLN 3817, ps. 1 ayat 3)

${ }^{23}$ Monopoli adalah penguasaan atas produksi dan/atau pemasaran barang dan/atau atas penggunaan jasa tertentu oleh satu pelaku usaha atau satu kelompok pelaku usaha. (Undang-Undang No.5 Tahun 1999 tentang Larangan praktek monopoli dan persaingan usaha tidak sehat, LN Tahun 1999 No. 33, TLN 3817, ps. 1 ayat 1) 
modern adalah masalah pengangguran. Di pasar tradisional terlibat jutaan pedagang, pemasok, pembeli kulakan dan penyedia jasa lainnya. Eksistensi pasar tradisional didukung secara padat karya beserta keragamannya. Berubahnya karakter pasar dari tradisional ke modern, berpotensi untuk menciptakan pengangguran dan kemiskinan baru. Karena berapa juta orang terlibat dalam jaringan pasar tradisional akan kehilangan mata pencahariannya bila pasar tradisional hancur. Kehancuran pasar tradisional akan menyebabkan ratusan juta jiwa penduduk Indonesia terancam kehilangan penghidupannya dan jatuh dalam kemiskinan absolut.

\section{Pengaturan Zonasi Berdasarkan}

\section{Peraturan Daerah Kota Surabaya Nomor}

\section{Tahun 2010}

Amanat dari Undang-Undang Nomor 32 Tahun 2004 adalah membentuk suatu daerah otonom ${ }^{24}$ bagi tiap daerah. Pergantian sistem pemerintahan tersebut berdampak positif khususnya terhadap Pemerintah Daerah, dimana Pemerintah Daerah melalui Otonomi Daerahnya (menurut asas otonomi) berwenang untuk mengatur dan mengurus sendiri urusan pemerintahan dan kepentingan masyarakat setempat seluasluasnya (kecuali urusan pemerintahan yang menjadi urusan pemerintah pusat, seperti: politik luar negeri, pertahanan, keamanan, yustisi, moneter dan fiskal serta

\footnotetext{
24 Daerah Otonom adalah kesatuan masyarakat hukum yang mempunyai batas-batas wilayah yang berwenang mengatur dan mengurus urusan pemerintahan dan kepentingan masyarakat setempat menurut prakarsa sendiri berdasarkan aspirasi masyarakat dan sistem Negara Kesatuan Republik Indonesia
}

agama) sesuai dengan peraturan perundang undangan yang berlaku.

Pergantian sistem pemerintahan tersebutberdampak positifterhadappenataan ruang, diantaranya adalah Pemerintahan Daerah dapat mengawasi pembangunan di daerahnya secara bertanggungjawab penuh sehingga pembangunan sesuai dengan aspirasi masyarakatnya. Penataan Ruang dalam Undang Undang Nomor 26 Tahun 2007 tentang Penataan Ruang (Lembaran Negara Republik Indonesia Tahun 2007 Nomor 68, Tambahan Lembaran Negara Republik Indonesia Nomor 4725) memiliki 3 (tiga) unsur yang saling terintegrasi, yaitu:

1. Perencanaan Tata Ruang

2. Pemanfaatan Ruang

3. Pengendalian Pemanfaatan Ruang

Yang penulis tekankan disini adalah unsur pengendalian pemanfaatan ruang. Unsur ini sebagaimana disebutkan dalam Pasal 1 angka 15 Undang Undang Nomor 26 Tahun 2007 bahwa "Pengendalian Pemanfaatan Ruang adalah upaya untuk mewujudkan tetib tata ruang". Dalam upaya pengendalian pemanfaatan ruang perlu ditindaklanjuti melalui pengaturan zona (zoning regulation). Peraturan zonasi(zoning regulation) adalah ketentuan yang mengatur tentang klasifikasi zona, pengaturan lebih lanjut mengenai pemanfaatan lahan, dan prosedur pelaksanaan pembangunan. Suatu zona mempunyai aturan yang seragam (guna lahan, intensitas, massa bangunan), namun satu zona dengan zona lainnya bisa berbeda ukuran dan aturan. 
Oleh karena itu Pemerintah Kota Surabaya melalui Otonomi Daerahnya, pada tanggal 12 Januari 2007, Pemerintah Kota Surabaya menerbitkan Peraturan Daerah kota Surabaya Nomor 3 Tahun 2007 tentang Rencana Tata Ruang Wilayah kota Surabaya (Lembaran Daerah Kota Surabaya Tahun 2007 Nomor 3, Tambahan Lembaran Daerah Kota Surabaya Nomor 3) sebagai implementasi dari terbitnya Undang Undang Nomor 26 Tahun 2007 tentang Penataan Ruang. Peraturan Daerah kota Surabaya Nomor 3 Tahun 2007 ini diterbitkan sebagai upaya Pengendalian Pemanfaatan Ruang di Surabaya agar berdayaguna, berhasilguna, serasi, selaras, seimbang dan berkelanjutan dalam rangka meningkatkan kesejahteraan masyarakat dan pertahanan keamanan.

MelaluiPeraturanDaerahkotaSurabaya Nomor 3 Tahun 2007 ini, Pemerintah Kota Surabaya membagi wilayah Kota Surabaya menjadi beberapa kawasan, antara lain:

1. Kawasan Lindung ${ }^{25}$ Wilayah Darat; meliputi:

a. Kawasan yang memberikan perlindungan pada kawasan bawahannya

b. Kawasan Perlindungan Setempat

c. Kawasan Cagar Budaya

d. Ruang Terbuka Hijau

2. Kawasan Lindung Wilayah Laut; meliputi:

\footnotetext{
${ }^{25}$ Kawasan Lindung adalah kawasan yang ditetapkan dengan fungsi utama melindungi kelestarian lingkungan hidup yang mencakup sumber daya alam dan sumber daya buatan (Peraturan Daerah kota Surabaya Nomor 3 Tahun 2007 tentang Rencana Tata Ruang Wilayah kota Surabaya, LD kota Surabaya Tahun 2007 No.3, TLD kota Surabaya No.3, ps. 1 angka 18.)
}
a. Kawasan Lindung/Konservasi Laut
b. Kawasan Lindung Mangrove

3. Kawasan Budidaya ${ }^{26}$ Wilayah Darat; meliputi:
a. Kawasan Pemerintahan
b. Kawasan Perumahan
c. Kawasan Fasilitas Umum
d. Kawasan Perdagangan dan Jasa
e. Kawasan Industri dan Pergudangan
f. Kawasan Pariwisata
g. Kawasan Khusus
h. Ruang untuk Prasarana dan Sarana Transportasi dan utilitas
i. Ruang untuk Jaringan Pematusan

4. Kawasan Budidaya Wilayah Laut; meliputi:
a. Kawasan Pengembangan Pantai
b. Kawasan Penangkapan Ikan
c. Kawasan Pariwisata Laut
d. Kawasan Alur Pelayaran

Dalam hal pembagian wilayah atau kawasan perdagangan dan jasa, Peraturan Daerah kota Surabaya Nomor 3 Tahun 2007 mengatur dalam Bab V Rencana Pemanfaatan Wilayah, bagian keempat: Kawasan Budidaya Wilayah Darat, yaitu:

\footnotetext{
${ }^{26}$ Kawasan Budidaya adalah kawasan yang ditetapkan dengan fungsi utama untuk dibudidayakan atas dasar kondisi dan potensi sumberdaya alam, sumber daya manusia dan sumber daya buatan (Peraturan Daerah kota Surabaya Nomor 3 Tahun 2007 tentang Rencana Tata Ruang Wilayah kota Surabaya, LD kota Surabaya Tahun 2007 No.3, TLD kota Surabaya No.3, ps. 1 angka 19.)
} 


\section{Pasal 50}

(1) Kawasan Perdagangan dan Jasa, merupakan kawasan yang dominansi pemanfaat ruangnya untuk kegiatan komersial perdagangan dan jasa pelayanan;

(2) Pembangunan fasilitas perdagangan dan jasa dilakukan dalam rangka mewujudkan kota Surabaya sebagai sentra perdagangan dan jasa dalam skala nasional maupun internasional;

(3) Kawasan perdagangan dan jasa ditetapkan tersebar pada setiap Unit Pengembangan kota Surabaya terutama di sekitar lokasi pusatpusat pertumbuhan sehingga dapat mengurangi kepadatan dan beban pelayanan di pusat kota.

(4) Pembangunan di kawasan perdagangan dan jasa dilakukan sebagai berikut:

a. Pusat kawasan komersial dan jasa dengan lingkup pelayanan skala Nasional, Regional dan Kota, berada di wilayah Unit Pengembangan (UP) VI Tunjungan yaitu di kawasan Basuki Rahmat, Embong Malang, Blauran, Praban, Bubutan, Pahlawan, Pasar Turi, Kapas Krampung dan Tunjungan di wilayah UP V Tanjung Perak yaitu di kawasan Jalan Perak Barat dan Timur, jalan Jembatan Merah dan jalan Kembang Jepun; b. Kawasan perdagangan dan jasa dengan skala pelayanan lingkungan sampai dengan kota tersebar pada setiap Unit Pengembangan terutama pada pusat-pusat pertumbuhan dengan memperhatikan daya dukung dan daya tamping ruang serta lingkup pelayanannya;

c. Kawasan perdagangan dan jasa direncanakan secara terpadu dengan kawasan sekitarnya dan harus memperhatikan kepentingan semua pelaku sektor perdagangan dan jasa termasuk pedagang informal ata pedagang sejenis lainnya;

d. Pada pembangunan fasilitas perdagangan berupa kawasan perdagangan terpadu, pelaksanaan pembangunan/ pengembangan wajib menyediakan prasarana lingkungan, utilitas umum, area untuk pedagang informal dan fasilitas sosial dengan proporsi $40 \%$ (empat puluh persen) dari keseluruhan luas lahan dan selanjutnya diserahkan kepada Pemerintah Daerah;

e. Pembangunan fasilitas perdagangan dan jasa harus memperhatikan kebutuhan luas lahan, jenis-jenis ruang dan fasilitas pelayanan publik yang harus tersedia, kemudahan pencapaian dan kelancaran sirkulasi lalu lintas dari dan 
menuju lokasi;

Dalam kaitan dengan masalah persaingan yang tidak seimbang antara pelaku usaha pasar modern dengan pasar tradisional yang marak terjadi di kotakota besar di Indonesia, akhirnya Presiden Republik Indonesia angkat bicara untuk menaggulangi masalah ini. Salah satu cara yang diterapkan adalah dengan menerbitkan Peraturan Presiden Nomor 112 Tahun 2007 tentang Penataan dan Pembinaan Pasar Tradisional, Pusat Perbelanjaan dan Toko Modern. Para pelaku usaha pada pasar tradisional banyak menaruh harapan akan nasib kelangsungan hidup mereka terhadap Peraturan Presiden Nomor 112 Tahun 2007 tersebut. Pada tahun 2008, Menteri Perdagangan Republik Indonesia juga menerbitkan Peraturan menteri Perdagangan Republik Indonesia Nomor: 53/M-DAG/ PER/12/2008 tentang Pedoman Penataan dan Pembinaan Pasar Tradisional, Pusat Perbelanjaan dan Toko Modern. Peraturan menteri Perdagangan Republik Indonesia Nomor: 53/M-DAG/PER/12/2008 ini merupakan tindak lanjut dari diterbitkannya Peraturan Presiden Nomor 112 Tahun 2007.

Harapan para pelaku usaha pada pasar tradisional harus berakhir, karena bila ditelaah lebih lanjut ketentuan yang termuat dalam Peraturan Presiden Nomor 112 Tahun 2007 dan Peraturan menteri Perdagangan Republik Indonesia Nomor: 53/M-DAG/ PER/12/2008, senyatanya lebih memihak kepada peritel bermodal besar, kedua regulasi tersebut dapat dikatakan masih bersifat abu-abu, karena aturan-aturan didalam regulaasi tersebut belum jelas, hanya mengatur mengenai pokok bab saja, kepentingan rakyat tidak dapat diakomodir oleh kedua regulasi tersebut. Pada saat menerbitkan Peraturan Presiden Nomor 112 Tahun 2007, Presiden Republik Indonesia, Susilo Bambang Yudhonoyo, mengatakan bahwa presiden hanya mengatur mengenai hal umum persaingan antara pasar modern dengan pasar tradisional dan pedagang kecil lainnya, harapan ke depannya adalah menjadi tanggungjawab pemerintah daerah melalui otonomi daerahnya untuk menerbitkan peraturan daerah yang berkaitan dengan masalah pasar tradisional dengan pasar modern yang gencar terjadi saat ini di hampir seluruh wilayah di tanah air.

Pertumbuhan toko modern khususnya minimarket di Surabaya bagai cendawan di musim hujan, cenderung tidak terkendali. Data yang direkam Pemerintah Kota Surabaya dan Dewan Pengurus Daerah Asosiasi Pengusaha Ritel Indonesia (APRINDO) berbeda. Dinas Perdagangan dan Perindustrian Kota Surabaya mencatat sampai akhir 2009 terdapat 346 minimarket di Surabaya. Sedangkan, Dewan Pengurus Daerah APRINDO Jawa Timur mencatat ada 475 minimarket di kota Surabaya ${ }^{27}$. Pertumbuhan minimarket memang sangat pesat di Jawa Timur maupun secara nasional. Di Jawa Timur ada 300-400 izin baru minimarket. Sampai akhir 2009, terdapat 4.250 minimarket di Jawa Timur, naik 677 (18,62\%) dari tahun 2008 yang 3.633 minimarket.

${ }^{27}$ Amril Amarullah, "Ritel Modern Surabaya Tidak Terkendali, ini Persoalan Pelik Bagi Kota Terbesar Kedua di Indonesia”, Surabaya Post, 24 Mei, 2010, h. 17. 
Bisnis minimarket di Indonesia memang sangat menggiurkan. Pada tahun 2008, APRINDO Jawa Timur mencatat total omzet minimarket di Jawa Timur mencapai Rp.9.41 triliun. Tahun 2009, jumlah omzet naik 20,03 persen menjadi Rp.11,49 triliun. Sedangkan tahun 2010, diprediksi peningkatan omzet berkisar 21,61 persen atau menjadi Rp.13,97 triliun ${ }^{28}$. Menggiurkannya bisnis minimarket inilah yang membuat pertumbuhannya makin tidak terkendali, termasuk di Surabaya. Dari 346 minimarket di Surabaya (berdasarkan data versi Dinas Perdagangan dan Perindustrian Kota Surabaya), 40 persennya tidak memiliki izin, baik itu izin zonasi, izin gangguan (Hinder Ordonantie) maupun izin mendirikan bangunan (IMB).

Pertumbuhan fenomenal toko modern salah satunya diakibatkan gencarnya penetrasi ritel asing ke Indonesia. Data BisInfocus 2008 menyebutkan, jika pada 1970-1990 pemegang merek ritel asing yang masuk ke Indonesia hanya lima, dengan jumlah 275 gerai, tahun 2004 sudah 14 merek ritel asing yang masuk, dengan 500 gerai. Tahun 2008, merek ritel asing sudah 18, dengan 532 gerai. Namun yang perkembangannya terbilang sangat cepat di Kota Surabaya yaitu Franchise ${ }^{29}$

\footnotetext{
${ }^{28}$ Ibid.

${ }^{29}$ Franchise atau waralaba adalah hak khusus yang dimiliki oleh orang perseorangan atau badan usaha terhadap sistem bisnis dengan ciri khas usaha dalam rangka memasarkan barang dan/atau jasa yang telah terbukti berhasil dan dapat dimanfaatkan dan/atau digunakan oleh pihak lain berdasarkan perjanjian waralaba (UndangUndang Nomor 42 Tahun 2007 tentang Waralaba, ps. 1 angka 1.)
}

minimarket:

1. Indomaret (PT Indomarco Prismatama)

2. Alfamart (PT Sumber Alfaria Trijaya Tbk)

3. Alfamidi (PT Midi Utama Indonesia, anak perusahaan dari PT Sumber Alfaria Trijaya Tbk)

4. Alfa Express (anak perusahaan dari PT Sumber Alfaria Trijaya Tbk)

\section{Circle K (PT Circle K Indonesia)}

Menyikapi amanat dari Peraturan Presiden Nomor 112 Tahun 2007 dan Peraturan menteri Perdagangan Republik Indonesia Nomor: 53/MDAG/PER/12/2008, Pemerintah Kota Surabaya menerbitkan Peraturan Daerah Kota Surabaya Nomor 1 Tahun 2010 tentang Penyelenggaran Usaha di Bidang Perdagangan dan Perindustrian (Lembaran Daerah Kota Surabaya Tahun 2010 Nomor 1, Tambahan Lembaran Daerah Kota Surabaya Nomor 1). Peraturan Daerah Kota Surabaya Nomor 1 Tahun 2010 ini merupakan tindak lanjut pemerintah kota Surabaya atas diterbitkannya Peraturan Presiden Nomor 112 Tahun 2007 tentang Penataan dan Pembinaan Pasar Tradisional, Pusat Perbelanjaan dan Toko Modern, dan Peraturan Menteri Perdagangan Nomor 53/M-DAG/PER/12/2008 tentang Pedoman Penataan dan Pembinaan Pasar Tradisional, Pusat Perbelanjaan dan Toko Modern sebagai peraturan pelaksanaannya. Memang benar materi yang diatur dalam Peraturan Daerah Kota Surabaya Nomor 1 Tahun 2010 
tersebut mengatur masalah pasar modern dan pasar tradisional, namun bila dianalisis lebih jauh Peraturan Daerah Kota Surabaya Nomor 1 Tahun 2010 ini masih dapat dikatakan bersifat abu-abu, karena aturannya belum jelas, hanya mengatur mengenai pokok bab saja, sama halnya dengan kedua peraturan diatasnya yang menjadi rujukan dibuatnya Peraturan Daerah Kota Surabaya Nomor 1 Tahun 2010 yaitu Peraturan Presiden Nomor 112 Tahun 2007 tentang Penataan dan Pembinaan Pasar Tradisional, Pusat Perbelanjaan dan Toko Modern dan Peraturan Menteri Perdagangan Nomor 53/M-DAG/PER/12/2008 tentang Pedoman Penataan dan Pembinaan Pasar Tradisional, Pusat Perbelanjaan dan Toko Modern.

Jika dikaitkan dengan masalah zonasi pasar antara pasar tradisional dengan pasar modern, Peraturan Daerah Kota Surabaya Nomor 1 Tahun 2010 mengaturnya dalam Pasal 37 yang berbunyi:

Lokasi untuk pendirian Toko Modern wajib memperhatikan:

a. Rencana Tata Ruang Wilayah kota;

b. Rencana Detail Tata Ruang Wilayah Kota, termasuk peraturan zonasinya;

c. Kondisisosialekonomimasyarakatdan keberadaan Pasar Tradisional, Usaha Mikro, Kecil dan Menengah yang ada di wilayah yang bersangkutan; dan

d. Jarak antara Toko Modern yang akan didirikan dengan Pasar Tradisional yang telah ada sebelumnya.

Materi muatan Pasal 37 Peraturan Daerah Kota Surabaya Nomor 1 Tahun 2010 diatas, hampir sama dengan materi muatan dalam Pasal 4 ayat (1) Peraturan Presiden Nomor 112 Tahun 2007, yang berbunyi:

Pendirian Pusat Perbelanjaan dan Toko Modern wajib:

a. Memperhitungkan kondisi sosial ekonomi masyarakat, keberadaan Pasar Tradisional, Usaha Kecil dan Usaha Menengah yang ada di wilayah yang bersangkutan;

b. Memperhatikan jarak antara hypermarket dengan pasar tradisional yang telah ada sebelumnya;

c. Menyediakan areal parkir paling sedikit seluas kebutuhan parkir 1 (satu) unit kendaraan roda empat untuk setiap $60 \mathrm{~m}^{2}$ (enam puluh meter per segi) luas lantai penjualan Pusat Perbelanjaan dan/atau Toko Modern; dan

d. Menyediakan fasilitas yang menjamin Pusat Perbelanjaan dan Toko Modern yang bersih, sehat (hygienis), aman, tertib dan ruang publik yang nyaman.

Kedua peraturan diatas dapat dinilai kurang spesifik mengatur hal mengenai jarak antara toko modern dengan pasar tradisional. Ketidakjelasan mengenai berapa jarak yang harus dipatuhi oleh pelaku usaha yang akan mendirikan pasar modernnya, akan menyebabkan eksistensi pasar tradisional semakin termarginalkan, sebab pemerintah kota Surabaya sendiri belum dapat melindungi kepentingan rakyat. Peraturan daerah yang diterbitkan oleh wakil rakyat seharusnya dapat melindungi kepentinga rakyatnya, bukan pihak lain. Norma dalam Pasal 37 Peraturan Daerah kota Surabaya 
Nomor 1 Tahun 2010 telah nyata merugikan kepentingan para pedagang dalam pasar tradisional, dimana banyak pasar tradisional di Surabaya yang di sekitarnya juga berdiri pasar modern, misalnya:

a. Pasar Kembang Vs Giant Diponegoro

b. Pasar Blauran Vs Carefour BG Junction

c. Pasar Pacar Keling Vs Indomaret dan Alfamart

d. Pasar Pagesangan Vs Indomaret

Hal ini terjadi karena Pemerintah Kota Surabaya belum mampu memberikan aturan yang jelas mengenai berapa jarak minimal yang harus dipenuhi oleh toko modern sebelum mendirikan suatu toko modern dengan pasar tradisional. Akibanya sudah nampak seperti yang penulis contohkan diatas, banyak toko modern yang pendiriannya berdekatan dengan pasar tradisional. Praktisi pasar di Surabaya dari PD Pasar Surya, menerangkan dalam sebuah diskusi di radio di Surabaya, bahwa menurunnya pasar tradisional, salah satunya disebabkan oleh ekspasi besar-besaran yang dilakukan oleh pelaku ritel modern dalam industri ritel ${ }^{30}$. Juru bicara PD Pasar Surya mengharapkan regulasi pemerintah yang melindungi pasar tradisional dari serbuan ritel modern yang kian terjepit.

Masalah utama dari Peraturan Daerah Kota Surabaya Nomor 1 Tahun 2010 adalah mengenai zonasi, namun tidak menutup kemungkinan ada masalah lain yang ditimbulkan oleh Peraturan

30 "Pasar Tradisional vs Pasar Modern", Suara Surabaya, diskusi, 26 Februari 2010
Daerah kota Surabaya ini. Masalah lain yang ditimbulkan oleh Peraturan Daerah Kota Surabaya Nomor 1 Tahun 2010 adalah pendirian toko modern khususnya minimarket vs minimarket yang jaraknya saling berdekatan. Contoh dari masalah ini adalah jarak antara minimarket Alfamart dengan minimarket Indomaret, masalah ini tidak hanya terjadi di kota Surabaya, namun juga terjadi di kota-kota di Pulau Jawa. Persaingan antar minimarket tersebut tidak tanggung-tanggung, minimarket yang menurut ketentuan pasal 5 ayat 4 Peraturan Presiden Nomor 112 Tahun 2007 berbunyi: "Minimarket boleh berlokasi pada setiap sistem jaringan jalan, termasuk sistem jaringan jalan lingkungan pada kawasan pelayanan lingkungan (perumahan) di dalam kota/perkotaan". Atas dasar inilah banyak minimarket yang mendirikan bangunannya di dalam perumahan, hingga masuk ke dalam perkampungan-perkampungan, dimanapada saat mendirikan bangunan tersebut, owners minimarket tersebut tidak memperhatikan berapa jumlah toko pedagang kecil yang ada disekitarnya, dan berapa jarak antar toko pedagang kecil tersebut dengan minimarket-nya. Sehingga disadari atau tidak, lambat laun toko pedagang kecil tersebut mengalami kebangkrutan akibat dari perubahan gaya hidup masyarakat di sekitar yang dahulu belanja dari toko kecil kini beralih ke minimarket.

Dengan tidak adanya aturan yang lebih detail mengenai minimarket, maka banyak pengusaha minimarket yang menggunakan dalil dalam Peraturan Presiden Nomor 112 Tahun 2007 dan/atau Peraturan 
Menteri Perdagangan Nomor 53/M-DAG/ PER/12/2008, dimana Peraturan Presiden Nomor 112 Tahun 2007 mengatur tentang minimarket dalam pasal 5 ayat 4 yang berbunyi: "minimarket boleh berlokasi pada setiap sistem jaringan jalan, termasuk sistem jaringan jalan lingkungan ${ }^{31}$ pada kawasan pelayanan lingkungan (perumahan) di dalam kota/perkotaan". Dalil ini yang digunakan sebagai alasan pembenar bahwa minimarket dapat berdiri di lokasi manapun bahkan di dalam perkampungan-perkampungan, padahal lokasi di perkampungan tersebut telah ada pedagang kecil yang menjajakan dagangan. Namun dengan berdirinya minimarket di dalam perkampungan ini, telah diyakini dapatmenyebabkan pedagangpedagang kecil di sekitar minimarket tersebut mengelami penurunan omzet, dan menyebabkan pedagang kecil tersebut tidak dapat menjalankan lagi usahanya karena kalah bersaing dengan minimarket yang merubah pola hidup masyarakat perkampungan untuk beralih belanja dari semula ke pedagang kecil kemudian beralih ke minimarket.

Strategiyangdigunakanolehminimarket untuk membuat konsumen beralih berbelanja ke minimarket juga beragam. Dari awal berdiri minimarket, memberikan promosi hadiah langsung dengan pembelian dengan nominal tertentu, misal dengan belanja Rp 25.000 akan mendapatkan hadiah langsung piring cantik, dengan belanja $\mathrm{Rp} 50.000$ akan mendapatkan hadiah langsung tumblr

31 Jalan lingkungan adalah merupakan jalan umum yang berfungsi melayani angkutan lingkungan dengan ciri perjalanan jarak dekat, dan kecepatan rata-rata rendah. Peraturan Presiden No.112 Tahun 2007, ps.5 ayat 9 air mineral, dengan belanja $\mathrm{Rp} 150.000$ akan mendapatkan hadiah langsung payung, dan seterusnya. Kemudian cara lain yang digunakan adalah dengan memberikan iming-iming hadiah kendaraan bermotor atau rumah dengan cara berbelanja produk di minimarket tersebut minimal Rp 50.000 akan mendapatkan satu kupon undian. Minimarket juga sering memberikan diskon atau potongan harga pada produk-produk tertentu agar konsumen berbelanja di minimarket. Strategi lain yang digunakan dapat juga dengan cara menerapkan prinsip pembelian kedua, misalnya harga minyak goreng pembelian pertama $\mathrm{Rp}$ 20.000, pembelian kedua produk yang sama hanya dengan membayar Rp 10.000, biasanya dibatasi maksimal 2 produk perhari perkonsumen. Padahal bila dihitung-hitung dan lebih meneliti lagi, harga produk yang dijual di toko pedagang kecil jauh lebih murah dari pada produk yang dijual di minimarket. Modus lain yang digunakan oleh pasar modern adalah dengan cara melakukan promosi midnight sale dimana konsumen melakukan transaksi jual beli pada pukul 21.00 keatas dengan iminngiming harga diskon 50\%-75\% produk tertentu dengan melakukan pembayaran dengan credit card atau member card pasar modern yang bersangkutan.

Toko modern melakukan beberapa strategi harga dan nonharga untuk menarik pembeli. Berdasarkan penelitian yang dilakukan oleh SMERU mereka melakukan berbagai strategi harga seperti strategi limit harga, strategi pemangsaan lewat pemangkasan harga (predatory pricing) 
dan diskriminasi harga antarwaktu (intertemporal price discrimination), misalnya memberikan diskon harga pada akhir minggu dan pada waktu tertentu. Sedangkan strategi nonharga antara laindalam bentuk iklan, membuka gerai lebih lama, khususnya pada akhir minggu, bunding/tying (pembelian secara gabungan) dan parkir gratis ${ }^{32}$.

Setelah "mengalahkan" pesaing bisnisnya yaitu pedagang kecil, muncul masalah lain bagi minimarket tersebut yaitu di sekitar minimarket-nya berdiri toko modern minimarket dengan nama perusahaan yang berbeda. Jarak antar minimarket tersebut juga sangat berdekatan, ada yang berhadap-hadapan langsung, bahkan ada yang berdiri berdampingan, hanya dibatasi oleh tembok toko. Pendirian minimarket kedua perusahaan tersebut telah menyebar hampir diseluruh pelosok kampung-kampung di Surabaya, akses untuk mengcapai minimarket tersebut juga mudah ditempuh oleh karena terlalu banyaknya pendirian minimarket ini. Fenomena ini terjadi oleh dua pengusaha minimarket ternama di Indonesia, yaitu Alfamart dan Indomaret. Masyarakat sudah dapat menerka bahwa,"dimana ada Indomaret, pasti tidak jauh dari minimarket tersebut ada Alfamart". Persaingan antar minimarket tersebut dari hari ke hari semakin menjadi. Mulai dari persaingan pelayanan terbaik, kebersihan hingga persaingan harga. Perang harga inilah yang mengkhawatirkan, disuatu

32 "kebijakan Publik Oleh Pemerintah Terhadap Pasar Tradisional dan Pasar Modern”, http://asaad36. blogspot.com/2010/11/kebijakan-___ publik-olehpemerintah.html, diakses pada tanggal 3 November 2010. konsumen memang merasa diuntungkan dengan harga yang murah dengan kualitas tinggi, namun disuatu sisi apabila misalnya Aflamart kalah bersaing dengan Indomaret, dan Indomaret menjadi satu-satunya pelaku bisnis dalam bidang ritel produk, maka Indomaret akan menguasai pasar dan Indomaret dapat mengatur harga dengan sesuka hatinya, karena tidak ada pesaing bisnis dan mau tidak mau konsumen akan membayar barang tersebut dengan harga yang mahal sebab konsumen membutuhkan produk tersebut.

Maka dari itu, Peraturan Daerah Kota Surabaya Nomor 1 Tahun 2010 memerlukan aturan mengenai dimana saja lokasi yang diperbolehkan minimarket didirikan agar tidak "mengusik" pedagang kecil yang ada di perkampungan-perkampungan di Surabaya. Juga perlu diatur mengenai jarak minimal dengan pedagang kecil dan atau dengan minimarket lain yang harus dipenuhi sebelum mendirikan minimarket di lokasi tersebut.

Masalah lain yang ditimbulkan oleh Peraturan Daerah Kota Surabaya Nomor 1 Tahun 2010, adalah mengenai jam kerja atau waktu operasional toko modern khususnya minimarket di Surabaya, Peraturan Daerah tersebut tidak mengatur mengenai waktu operasional toko modern sebagaimana telah diatur dalam Peraturan Presiden Nomor 112 Tahun 2007 pasal 7 yang berbunyi:

Pasal 7

(1) Jam kerja hypermarket, Department Store dan Supermarket adalah sebagai berikut: 
a. Untuk hari Senin sampai dengan jumat, pukul 10.00 sampai dengan pukul 22.00 waktu setempat.

b. Untuk hari Sabtu dan Minggu, pukul 10.00 sampai dengan pukul 23.00 waktu setempat.

(2) Untuk hari besar keagamaan, libur nasional atau hari tertentu lainnya, Bupati/Walikota atau Gubernur untuk Pemerintah Provinsi Daerah Khusus Ibukota Jakarta dapat menetapkan jam kerja melampaui 22.00 waktu setempat.

Melihat dari ketentuan diatas sudah jelas bahwa pasal 7 ayat 1 Peraturan Presiden Nomor 112 Tahun 2007 tidak dapat disimpangi oleh siapapun, dalam artian aturan ini adalah aturan baku yang tidak dapat dirubah-rubah. Namun jika melihat ketentuan pasal 7 ayat 2 Peraturan Presiden Nomor 112 Tahun 2007, Bupati/ Walikota atau Gubernur untuk Pemerintah Provinsi Daerah Khusus Ibukota Jakarta dapat menyimpanginya dengan mengatur jam kerja toko modern dapat melebihi pukul 22.00 waktu setempat tergantung kebijakan yang nanti akan dikeluarkan.

Peraturan Daerah Kota Surabaya Nomor 1 Tahun 2010 tidak mengatur mengenai jam kerja bagi toko modern di Surabaya. Ketatnya persaingan ritel di kota Surabaya menyebabkan pelaku bisnis ritel melakukan berbagai inovasi agar bisnis ritelnya dapat bertahan ditengah derasnya persaingan usaha di Surabaya. Inovasi yang dilakukan oleh pelaku bisnis ritel ini yang berupa toko modern khususnya minimarket seperti Alfamart, Indomaret dan Cicle-K melakukan perubahan jam kerja yang semula jam buka dari jam 10.00-22.00, kini waktu operasionalnya 7hari/24 jam nonstop. Inovasi yang dilakukan minimarket ini telah jelas-jelas melanggar ketentuan dalam Peraturan Presiden Nomor 112 Tahun 2007 pasal 7.

Masalah lainnya adalah masalah infrastruktur yang hingga kini masih menjadi masalah serius di pasar tradisional yang kurang populer di kalangan pembeli, kebersihan dan tempat pembuangan sampah yang kurang terpelihara, kurangnya lahan parkir dan buruknya sirkulasi udara. Belum lagi ditambah semakin menjamurnya pedagang kaki lima (PKL) yang otomatis merugikan pedagang yang berjualan di dalam lingkungan pasar yang harus membayar penuh sewa dan retribusi. PKL menjual barang dagangan yang hampir sama dengan seluruh produk yang dijual di dalam pasar, dengan demikian pembeli tidak perlu masuk ke dalam pasar untuk berbelanja karena mereka dapat membeli dari PKL di luar pasar.

Maka dari itu, ini merupakan tugas berat bagi PD Pasar Surya untuk segera me-revitalisasi pasar-pasar tradisional yang ada di kota Surabaya untuk meningkatkan kenyamanan di pasar tradisional agar tidak terkesan becek, bau, kotor dan banyak terjadi pencurian, agar konsumen dapat betah berbelanja di pasar tradisional. Pedagang di pasar tradisional juga mempunyai tugas untuk meningkatkan kepuasan konsumen melalui peningkatan kualitas produk yang dijajakan, pelayanan kepada konsumen 
dan juga yang paling penting mengenai harga yang ditentukan oleh pedagang pasar tradisional, agar tidak kalah bersaing dengan pasar modern. Dengan adanya tempat berbelanja yang nyaman dan pelayanan yang ramah oleh pedagang pasar tradisional, maka dengan sendirinya konsumen akan beralih kembali berbelanja di pasar tradisional. Jadi dengan adanya solusi ini, konsumen sekarang dapat memilih apakah tetap berbelanja di pasar modern ataukah akan beralih kembali kepada pasar tradisional.

Sebuah penelitian di sebuah media $\operatorname{cetak}^{33}$ menyebutkan bahwa dengan memilih pasar tradisional sebagai tempat berbelanja kebutuhan sehari-hari, maka konsumen telah berjasa dalam penghematan penggunaan bahan bakar. Sayur dan buahbuahan di pasar tradisional adalah produksi dari daerah yang terdekat. Sedangkan di supermarket, banyak produk-produk yang merupakan hasil impor. Selain selalu tersaji segar, harga di pasar tradisional pun lebih murah dibandingkan di supermarket. Bayangkan berapa banyak energi yang dibutuhkan untuk mengirim produk-produk itu ke supermarket. Selain berguna bagi lingkungan, berbelanja di pasar tradisional juga turut memajukan perekonomian daerah.

\section{Kesimpulan}

Ketidakjelasaan pengaturan yang lebih umum mengenai zonasi dalam Peraturan Presiden Nomor 112 Tahun 2007 dan Peraturan Menteri Perdagangan Nomor

${ }^{33}$ Aisyah, "Mendukung Pasar Tradisional", Jawa Pos, edisi 12 April 2009
53/M-DAG/PER/12/2008 menimbulkan suatu perbedaan interprestasi bagi setiap pemerintah daerah, sehingga produk hukum yang dihasilkan tiap pemerintah daerah salah satunya pemerintah kota surabaya yang menerbitkan Peraturan Daerah Kota Surabaya Nomor 1 Tahun 2010 dirasa hanya memihak kepada peritel besar, seharusnya peraturan yang diterbitkan oleh pemerintah harus memihak kepada rakyat khususnya pelaku usaha dalam pasar tradisional yang mayoritas menjalankan usahanya dengan modal kecil dibandingkan dengan pasar modern yang disokong oleh pengusaha dengan modal kuat.

Aturan hukum yang diatur di Peraturan Daerah Kota Surabaya Nomor 1 Tahun 2010 belum mampu meng-cover kepentingan pelaku usaha khususnya pelaku usaha dalam pasar tradisional, karena norma di dalam Peraturan Daerah Kota Surabaya Nomor 1 Tahun 2010 kurang mengikat bagi pelaku usaha pasar modern, dimana hanya mengatur mengenai ketentuan untuk memperhatikan keberadaan pasar tradisional, tanpa diatur mengenai berapa jarak minimal yang harus dipatuhi oleh calon pelaku usaha pasar modern untuk mendirikan bangunan pasar modern. Akibat dari tidak adanya aturan yang lebih konkrit lagi mengenai zonasi pasar tradisional dengan pasar modern, menyebabkan posisi pasar tradisional semakin termarginalkan. 


\section{DAFTAR PUSTAKA}

Arif, Saiful, "Nasib Pasar Tradisional di Indonesia", http://gagasanhukum. wordpress. com/2009/12/, 2009, diakses pada tanggal 22 Juli 2010.

Aisyah, "Mendukung Pasar Tradisional", Jawa Pos, edisi 12 April 2009.

Amarullah, Amril, "Ritel Modern Surabaya Tidak Terkendali, ini Persoalan Pelik Bagi Kota Terbesar Kedua di Indonesia”, Surabaya Post, 24 Mei, 2010.

Anna, Apriana, "Pasar Tradisional vs Pasar Modern", http://aprianaanna.blogspot.com/2010/05/pasartradisional-vs-hypermart.html, diakses pada tanggal 24 Juni 2010.

Departemen Pendidikan dan Kebudayaan, Kamus Besar Bahasa Indonesia, Balai Pustaka, 1989, h.767.

Ibrahim, Johny, Hukum Persaingan Usaha, Filosofi, Teori, dan Imlikasi Penerapannya di Indonesia, Bayumedia Publishing, Malang, 2006, h.103, dikutip dari Michael E. Porter, Competitive Advantage, Creating and Sustaining Superior Performance Edisi Indonesia: Keunggulan Bersaing Menciptakan dan Mempertahankan Konerja Unggul, alih bahasa: Agus Dharma dkk., Erlangga, Jakarta, 1993.

Jurusan Sejarah Universitas Airlangga, Kota Lama, Kota Baru: Sejarah kota-kota di Indonesia Sebelum dan Setelah Kemerdekaan, Ombak, Yogyakarta, 2005
"Kebijakan Publik Oleh Pemerintah Terhadap Pasar Tradisional dan Pasar Modern", http://asaad36.blogspot. com/2010/11/kebijakan-_publik-olehpemerintah.html, diakses pada tanggal 3 November 2010.

Marzuki, Ismail, "Zoning", http://imazu. wordpress.com/zoning/, diakses pada tanggal 10 Oktober 2010.

\section{Peraturan Presiden No.112 Tahun 2007.}

Ras Ginting, Elyta, Hukum Anti Monopoli Indonesia(Analisis dan Perbandingan Undang-Undang Nomor 5 Tahun 1999), Citra Aditya Bakti, Bandung, 2001.

Rahmawati, Tjatur Endang, "Minimarket Terancam Tutup, Tanpa Izin Usaha Toko Modern", Surya, 7 Mei, 2010.

Suara Surabaya, "Pasar Tradisional vs Pasar Modern", diskusi, 26 Februari 2010

Undang-Undang No. 5 tahun 1999 tentang Larangan Praktek Monopoli dan Persaingan Usaha Tidak Sehat,

Undang-Undang Nomor 42 Tahun 2007 tentang Waralaba.

Yani Ahmad dan Gunawan Widjaja, Seri Hukum Bisnis: Anti Monopoli, Raja Grafindo Persada, Jakarta, 2000. 